Teologia i Moralność, Volumen 13(2018), numer 1(23)

doi: $10.14746 / \mathrm{tim} .2018 .23 .1 .10$

PIOTR OLSZANOWSKI

Bydgoszcz

\title{
Problematyka rozumienia porządku moralnego w perspektywie milosierdzia rozpoznawana przez dobrze uksztaltowane sumienie w adhortacji apostolskiej Amoris laetitia
}

Troska o dobro rodziny zawsze zajmowała ważne miejsce w nauczaniu Kościoła, który świadomy tego, ,że małżeństwo i rodzina stanowią jedno z najcenniejszych dóbr ludzkości” (FC, nr 1), wielokrotnie pochylał się nad zagadnieniami związanymi z ,głęboką wspólnotą życia i miłości” (KDK, nr 48). Głos w debacie na temat rodziny jest istotny szczególnie dzisiaj, kiedy to dotknięta zostaje ona dynamiką głębokich zmian na płaszczyźnie kulturowej i społecznej. Wśród zawiłych i krętych dróg współczesnego pluralizmu łatwo jest się zagubić i zboczyć z właściwej ścieżki, a po utracie odpowiedniej perspektywy i bezpiecznego gruntu nietrudno o zranienia. Rzucona w ciernie dzisiejszego świata rodzina narażona jest na wiele niebezpieczeństw, z których trudno jest wyjść obronną ręką. Zmagając się z problemami wymagającej codzienności, chrześcijańska rodzina często przybiera postać „rodziny poranionej" (AL, nr 203), która potrzebuje uleczenia olejem miłosierdzia. Niezależnie jednak od tego, jak bardzo „dana rodzina może być poraniona, zawsze może się ona rozwijać wychodząc od miłości” (Franciszek 2015b, nr 10). Miłość jest zatem czynnikiem decydującym. Już papież Jan Paweł II w adhortacji apostolskiej Familiaris consortio, stwierdził, że miłość powinna być zawsze początkiem i siłą komunii małżeńskiej (por. FC, nr 18). Jest ona wobec tego tą mocą, która pociąga mężczyznę i kobietę do budowania rodzinnej wspólnoty. Dostrzegając trudną i zawiłą sytuację współczesnych rodzin, także papież Franciszek w adhortacji apostolskiej Amoris laetitia proponuje spojrzenie na rodzinę poprzez pryzmat miłości, która jest siłą uzdrawiającą i budującą. $\mathrm{Na}$ szczególną uwagę zasługuje, że jest to spojrzenie pełne miłości miłosiernej 
i uzdrawiającej, a sam dokument podpisany został w Roku Jubileuszowym Miłosierdzia.

Poniższy artykuł jest próbą interpretacji najnowszej adhortacji papieża Franciszka z punktu widzenia wielopłaszczyznowych trudności, z jakimi spotykają się współczesne rodziny i małżeństwa w zakresie norm i zasad moralności. Kluczem rozumienia papieskiego dokumentu staje się tajemnica Bożego miłosierdzia, często przez papieża akcentowana. Uzdrawiający dotyk miłości miłosiernej stanowi niezbędne remedium, które leczy i zabliźnia rany dzisiejszych małżeństw i rodzin.

\section{Odpowiednie rozpoznanie}

Niezwykle istotny okazuje się rozdział VIII dokumentu, któremu to papież nadaje znaczący podtytuł: „Towarzyszyć, rozpoznać i włączyć to, co kruche” (AL, nr. 291-312). Adhortacja apostolska Amoris laetitia może być interpretowana $\mathrm{z}$ uwzględnieniem wielu aspektów, a użyte tutaj czasowniki stanowią jeden $\mathrm{z}$ nich. Przedstawione słowa występują razem, tuż obok siebie i w swoistym związku synergicznym, a jako cel obierają sobie kruchość, ulotność oraz subtelność w stosunku do ludzkiego życia. „Towarzyszyć” to czasownik, który odsyła do tajemnicy wcielenia, gdzie „Bóg z nami” (Rz 8,31), przez co Kościół staje się Kościołem dla ludzi. „Rozpoznać” to z kolei klucz do życia chrześcijańskiego wraz z całym jego bagażem delikatności oraz wrażliwości, co chrześcijańska tradycja potwierdziła poprzez rozwijanie odmiennych postaci rozeznania. „Włączyć” to cel fundamentalny Kościoła rozumianego jako Lud Boży. Nie chodzi tu o Kościół dla elit, dla osób nieskazitelnych i w jakiś sposób wyróżnionych, ale o Kościół dla wszystkich, bo zbawienie jest darem włączającym ogół rodzaju ludzkiego, nawet osoby najbardziej poranione skutkami grzechu (por. Yáñez 2016a, s. 15). Miejsce ukojenia mogą oni odnaleźć w Kościele, którego zadanie często podobne jest do „szpitala polowego” (AL, nr 291).

Zastosowany w tekście zabieg stylistyczny, polegający na zestawieniu ze sobą trzech czasowników, nabiera szczególnego znaczenia w odniesieniu do miłosierdzia, które wyrasta na kryterium przewodnie całego pontyfikatu papieża Franciszka. W bulli otwierającej Rok Miłosierdzia papież stwierdził, że „miłosierdzie to nie jest tylko działanie Ojca, lecz staje się kryterium pozwalającym zrozumieć, kim są Jego prawdziwe dzieci. Jesteśmy więc wezwani do życia miłosierdziem, ponieważ to my najpierw doznaliśmy miłosierdzia" (MV, nr 12). Według papieża Kościół jest wspólnotą miłosierdzia, która nie może pozostać obojętna w obliczu ludzkich dramatów, szczególnie tych, które dotykają współczesną rodzinę. 
Przez pryzmat miłości uzdrawiającej należy spojrzeć także na wspomniany już rozdział VIII, rozpoczynający się od potwierdzenia tożsamości osoby ochrzczonej, która nigdy nie powinna zostać przez Kościół opuszczona, choćby nawet zdarzyło się, że osoby ochrzczone rozwiodły się i zawarły ponowny związek cywilny (por. AL, nr 299). W takiej sytuacji Kościół powinien ukazywać się jako matka pełna miłosierdzia lub jak ojcowski dom, ,gdzie jest miejsce dla każdego z jego trudnym życiem" (AL, nr 310). Z jednej strony $\mathrm{w}$ indywidualne rozpoznanie personalne określnej sytuacji włączony zostaje wymiar eklezjalny, a zatem, osobisty proces rozpoznania dokonuje się we wspólnocie wierzących oraz w relacji i dialogu z nauczaniem Kościoła, gdzie szuka się zrozumienia woli Bożej w odniesieniu do osoby w jej specyficznej sytuacji. W tym kontekście warto przypomnieć rozumienie katolickiej nauki na temat sumienia $\mathrm{i}$ jego kompetencji. Oto co w tej kwestii podpowiada papież Franciszek: „Z trudem dajemy też miejsce dla sumienia wiernych, którzy pośród swoich ograniczeń często odpowiadają najlepiej jak potrafią na Ewangelię i mogą rozwijać swoje własne rozeznanie w sytuacji, gdy wszystkie systemy upadają. Jesteśmy powołani do kształtowania sumień, nie zaś domagania się, by je zastępować" (AL, nr 37). Wydaje się, że zgłębienie zagadnień i pochylenie się nad kwestią sumienia w odniesieniu do właściwej percepcji małżeństwa leży w centrum zainteresowań papieża Franciszka, tym bardziej że w swojej adhortacji apostolskiej zaznacza, iż ,świadomi wagi konkretnych uwarunkowań, możemy dodać, że ludzkie sumienie powinno być lepiej włączone do praktyki Kościoła w niektórych sytuacjach, które obiektywnie odbiegają od naszego rozumienia małżeństwa" (AL, nr 303).

\section{Aplikacja norm moralnych}

Amoris laetitia funkcjonuje w świadomości ogółu jako dokument pastoralny i duszpasterski. Odczytywanie adhortacji apostolskiej w ten sposób jest jednym z kluczy jej interpretacji. To jednak nie jedyny sposób, w jaki można się pochylić nad papieskim dokumentem. Dyrektor Departamentu Teologii Moralnej na Papieskim Uniwersytecie Gregoriańskim, profesor Humberto Miguel Yáñez, w jednym z wywiadów zaznaczył, że kto odczytuje dokument jedynie w kategorii pastoralnej, ryzykuje osłabienie jego przesłania. Zdaniem teologa moralisty, nie można tracić z oczu również aspektu normatywnego, jaki niesie ze sobą papieski dokument (Yáñez 2016a, s. 15), choć trzeba zaznaczyć, że i takie spojrzenie powinno odbywać się przez pryzmat miłosiernej miłości. Zagadnienia związane $\mathrm{z}$ aplikacją poszczególnych norm moralnych dostrzegalne są $\mathrm{w}$ dokumencie szczególnie w odniesieniu do przywołania nauczania św. Tomasza w zakresie prawa naturalnego. 
Amoris laetitia nie pretenduje do tego, aby zmieniać normatywność sformułowaną we wcześniejszych dokumentach papieskich, ale jej autor podejmuje wysiłek, aby doprecyzować, w jaki sposób stosować normy moralne. Warto zauważyć, że nie wszystkie normy prawa moralnego mają tę samą wagę, bo przecież obok norm niezmiennych są i te, które nie tylko mogą podlegać ponownemu sformułowaniu, ale mogą też być zmienione czy zniesione przez kompetentną władzę kościelną, a taką władzę ma papież. Jak przypomina Sobór Watykański II, papież „cieszy się z ustanowienia Bożego najwyższą, pełną, bezpośrednią i powszechną władzą" (DB, nr 2).

W odniesieniu do norm moralnych papieski dokument odsyła do nauczania św. Tomasza z Akwinu. Według Akwinaty normy moralne są bardzo ważne, ale mają ograniczenia, a moralność chrześcijańska nie powinna być zredukowana tylko do moralności norm.

Chociaż w ogólnych zasadach istnieje jakaś konieczność, to jednak im bardziej schodzi do poszczegółów, tym łatwiej o uchybienia. [...] w dziedzinie postępowania nie we wszystkich jest ta sama prawda lub poprawność działania, gdy chodzi o szczegóły, a tylko gdy chodzi o ogólne zasady. A i u tych, w których jest ta sama poprawność w poszczególnych sprawach, nie jest wszystkim znana w równym stopniu. [...] Im bardziej schodzi się w szczegóły tym ów wniosek ukazuje się zawodny i trudniejszy do zastosowania (Tomasz z Akwinu 1986, s. 34-35) ${ }^{1}$.

Odwołując się do nauczania św. Tomasza, papież dodaje w Amoris laetitia, że „normy ogólne stanowią pewne dobro, którego nigdy nie powinno się ignorować lub zaniedbywać, ale w swoich sformułowaniach nie mogą obejmować absolutnie wszystkich szczególnych sytuacji” (AL, nr 304). Według Akwinaty prawo moralne naturalne nie redukuje się do katalogu nakazów, które powinny być praktykowane w sposób absolutny. Jest on świadomy ograniczeń, gdyż niemożliwe jest przewidzenie wszystkich przypadków, w których określona norma będzie miała zastosowanie. Dlatego Amoris laetitia, powołując się na Międzynarodową Komisję Teologiczną, przywołuje ideę prawa moralnego naturalnego jako źródła inspiracji dla osobistych zabiegów podmiotu moralnego podczas podejmowania decyzji, albowiem ,prawo naturalne nie może być przedstawiane jako zbiór już ustanowionych reguł, które narzucają się a priori moralnemu podmiotowi” (AL, nr 305). Ponadto, tradycja uznała zdolność

${ }^{1}$ Tomasz z Akwinu, Summa Theologiae I-II, q. 94, a. 4: Ideo, etsi in communibus sit aliqua necessitas, quanto magis ad propria descenditur, tanto magis invenitur defectus. [...] In operativis autem non est eadem veritas vel rectitudo practica apud omnes quantum ad propria, sed solum quantum ad communia, et apud illos apud quos est eadem rectitudo in propriis, non est aequaliter omnibus nota. [...] Et hoc tanto magis invenitur deficere, quanto magis ad particularia descenditur, puta si dicatur quod deposita sunt reddenda cum tali cautione. 
podmiotu działającego do rozpoznawania, nie tylko w przypadku, gdy nie istnieje jakaś norma, ale również $\mathrm{w}$ całym procesie indywidualizacji aplikacji normy praktycznej w konkretnej sytuacji, gdzie kryterium definitywne stanowi integralne dobro osoby (Yáñez 2016b, s. 45). Moralność chrześcijańska jest bowiem moralnością rozpoznania według tego, czego nauczał św. Paweł: „przemieniajcie się przez odnawianie umysłu, abyście umieli rozpoznać, jaka jest wola Boża: co jest dobre, co Bogu przyjemne i co doskonałe" (Rz 12,2).

Rozum praktyczny podczas aplikacji zasady ogólnej do konkretnego przypadku niesie w sobie jednocześnie funkcje przewidywania konsekwencji i oceny proporcji; jednak jest to rzeczą różną od radykalizacji tych funkcji, co zostało skrytykowane przez papieża Jana Pawła II w encyklice Veritatis splendor w postaci konsekwencjonalizmu oraz proporcjonalizmu (Yáñez 2016b, s. 45). Chociaż kierunki te stanowią próbę wypracowania racjonalnej moralności, to jednak ,prowadzą nieraz do fałszywych rozwiązań, wynikających zwłaszcza z niewłaściwego rozumienia przedmiotu działania moralnego" (VS, nr 75). W tym kontekście $\mathrm{z}$ adhortacji apostolskiej dowiadujemy się, że „konsekwencje lub skutki danej normy niekoniecznie muszą być takie same” (AL, nr 300) oraz że „skutki popełnionych czynów nie muszą być takie same w każdym przypadku" (AL, nr 302).

\section{Porządek moralny}

W rozdziale VIII adhortacji apostolskiej Amoris laetitia poruszana jest również kwestia odpowiedniego porządku norm moralnych. To bardzo interesujący wątek w odniesieniu do poruszanych w papieskim dokumencie zagadnień dotyczących miłości w rodzinie i trudności wynikających z prawidłowej realizacji zobowiązań małżeńskich. Perspektywa poglądów ukazana w dokumencie jest wypadkową tradycyjnego nauczania Kościoła na temat miłości małżeńskiej, choć zaznaczyć trzeba, że papież z Argentyny nie zacieśnia swoich poglądów tylko do retrospekcji wcześniej zarysowanej linii poglądowej, ale rozwija ją w duchu nauczania posoborowego, biorąc pod uwagę realia współczesności, szczególnie te, które dotykają dzisiejsze małżeństwa i rodziny.

W tym kontekście cenne jest przypomnienie tego, jak kształtował się dyskurs moralny podczas ostatniego soboru w odniesieniu do porządku moralnego, a także związanego z nim zagadnienia sumienia. Na podstawie kreślonej przez Amoris laetitia wizji sumienia oraz jego funkcji we właściwym rozeznaniu można dojść do przekonania, że Franciszek stoi po stronie ojców soborowych, którzy w pracach nad tworzeniem Gaudium et spes dalecy byli od przyjęcia kierunku proponowanego przez schemat De ordine morali christia- 
no (Maiorano 1987, s. 261). Dokument ten wskazywał na pasywność sumienia, które ,jako sług a prawa, po wcześniejszym dokonaniu selekcji według określonej specyfikacji aktu, jest praktycznie zredukowane do prostego stanu możliwości przypisania danego aktu jako grzech lub jako zasługa"². Takie ujęcie tematu podkreślało bierny charakter sumienia wraz $\mathrm{z}$ jego funkcją sądu, którego zadaniem jest aplikacja normy moralnej oraz ,jako środka pośredniczącego między porządkiem moralnym a poszczególnymi wierzącymi”" (Olszanowski 2015, s. 11). Sumienie w takim ujęciu zredukowane zostaje do biernego instrumentu, którego zadaniem jest zastosowanie sądu praktycznego. Z kolei końcowy tekst Konstytucji duszpasterskiej o Kościele w świecie współczesnym prezentuje ten temat z punktu widzenia innej optyki, takiej, jaką odkryć można w spojrzeniu Franciszka. W Gaudium et spes mowa jest już o godności sumienia, ukazującego się już nie tylko jako refleksja nad porządkiem moralnym, ale będącego „najtajniejszym ośrodkiem i sanktuarium człowieka, gdzie przebywa on sam z Bogiem, którego głos w jego wnętrzu rozbrzmiewa" (KDK, nr 16). Człowiek w swoim wnętrzu spotyka się z osobowym Bogiem, a nie z prawem i porządkiem niezbędnych współistniejących relacji (por. Maiorano 1987, s. 270). Ważnym elementem nauczania Gaudium et spes na temat sumienia i porządku moralnego jest oderwanie się od porządku niezbędnych relacji oraz przybliżenie rzeczywistości ekonomii zbawienia, w której prawda sumienia nie sprowadza się tylko do aplikacji spersonalizowanych norm (por. Maiorano 1987, s. 272). Sumienie przybiera dynamiczny i aktywny charakter, ujawniający się w poszukiwaniu prawdy moralnej.

W argumentacji kreślonej przez Franciszka w Amoris laetitia pobrzmiewa linia nakreślona przez ojców soborowych. W ostatnim punkcie podrozdziału zatytułowanym „Stopniowość w duszpasterstwie” można także dostrzec kontynuację wcześniejszego nauczania papieskiego, zaprezentowanego w Familiaris consortio, a dotyczącego porządku moralnego. Franciszek wprost przywołuje dokonania papieża Polaka, gdy próbując określić, czym jest porządek moralny, powołuje się na 34. punkt adhortacji o zadaniach rodziny chrześcijańskiej, gdzie ów porządek zdefiniowany został następująco:

Porządek moralny, właśnie dlatego, że ujawnia i przedstawia zamysł Boży, nie może być czymś, co utrudnia życie człowiekowi i co nie odpowiada osobie; wręcz przeciwnie, odpowiadając najgłębszym potrzebom człowieka stworzonego przez Boga, służy jego pełnemu człowieczeństwu z tą samą subtelną i wiążącą miłością, z jaką sam Bóg pobudza, podtrzymuje i prowadzi do właściwego mu szczęścia każde stworzenie (FC, nr 34).

${ }^{2}$ Ograniczam się do wyciągnięcia najistotniejszy elementów, gdyż więcej na temat pisałem w artykule: Olszanowski 2015, s. 205-218. 
Wydaje się, że odwołanie się w Amoris laetitia do porządku moralnego nakreślonego przez Jana Pawła II ma za zadanie uczynić proces rozeznania trudnych sytuacji małżonków bardziej usystematyzowanym i ma służyć głębokiej oraz szczegółowej analizie określonych przypadków. Mowa jest zatem o porządku moralnym w odniesieniu do sytuacji małżeństw niesakramentalnych. Dokładniej ujmując, mamy tutaj na uwadze liczne pary rozwiedzione, które ponownie zawarły związek cywilny i zmagają się z wieloma problemami związanymi z próbą życia w nieustannej nadziei zbliżenia do sakramentu Eucharystii oraz są świadome zagrożenia dla ich życia duchowego, także tymi, które może wywołać brak pełnej komunii małżeńskiej. Amoris laetitia opisuje to w następujący sposób: „Osoby rozwiedzione, żyjące w nowym związku, mogą na przykład znaleźć się w bardzo różnych sytuacjach, które nie powinny być skatalogowane lub zamknięte $\mathrm{w}$ zbyt surowych stwierdzeniach, nie pozostawiając miejsca dla odpowiedniego rozeznania osobistego i duszpasterskiego" (AL, nr 298). Odpowiednie rozeznanie duszpasterskie pozwala ominać ciasne ramy schematyzmu, wyjść poza wąski horyzont katalogów oraz spojrzeć na określone przypadki z perspektywy bezgranicznie ogarniającej wszystkich miłości miłosiernej. Z tego powodu Franciszek podkreśla, aby „unikać osądów, które nie uwzględniają złożoności różnych sytuacji i koniecznie zwracać uwagę na sposób, w jaki ludzie żyją i cierpią z powodu stanu, w jakim się znajdują" (AL, nr 296; Franciszek 2015b). Norma prawa moralnego, która przypisana jest wartości ludzkiej, nie powinna być pojmowana w stanie izolacji i odseparowania od sytuacji rzeczywistej, przeciwnie, powinna zostać włączona w realizację dobra i wartości, które wyrażają i pozwalają na spełnienie życia w relacji z innymi, ze wspólnotą oraz Bogiem wcielonym w historię życia ludzkiego.

W odniesieniu do sytuacji osób, o których papieski dokument pisze, że znajdują się w tak zwanej sytuacji nieregularnej (por. AL, nr 301), brak spójności z normą nie powinien być automatycznie postrzegany jako stan grzechu śmiertelnego. „Dlatego nie można już powiedzieć, że wszyscy, którzy są w sytuacji tak zwanej «nieregularnej», żyją w stanie grzechu śmiertelnego, pozbawieni łaski uświęcającej” (AL, nr 301). W adhortacji Amoris laetitia, która powołuje się na Familiaris consortio, możemy natknąć się na wskazania mówiące o istnieniu trudności w rozumieniu „wartości zawartych w normie moralnej" (AL, nr 301; FC 33). W tym kontekście papież Franciszek w swoim dokumencie pamięta o zaproponowanym przez Jana Pawła II tak zwanym prawie stopniowalności w stosunku do owych wartości. Co ważne, nie należy dopatrywać się tutaj tożsamości ze stopniowalnością prawa, ale odczytywać je w kategoriach stopniowalności „w roztropnym wypełnianiu wolnych aktów w podmiotach, które nie są w stanie zrozumieć, docenić lub w pełni realizować wymogów prawa” (AL, nr 295), albowiem człowiek ,powołany do świadomego wypełnienia mądrego i pełnego miłości zamysłu Bożego, jest 
istotą historyczną, która się formuje dzień po dniu, podejmując liczne i dobrowolne decyzje: dlatego poznaje, miłuje i czyni dobro moralne, odpowiednio do etapów swego rozwoju" (FC, nr 34). Etap dojrzewania człowieka względem pojmowania normy moralnej jest procesem długotrwałym, skomplikowanym i wieloaspektowym. Chociaż człowiek rozwija się ,powoli przez stopniowe włączanie darów Bożych i wymagań Jego ostatecznej i najdoskonalszej Miłości w całe życie osobiste i społeczne człowieka" (FC, nr 9), to nigdy nie pozostaje poza kręgiem zainteresowania Boga, który pragnie obdarzyć go darem zbawienia. Niejednokrotnie trudności w rozumieniu „wartości zawartych w normie moralnej" (AL, nr 301; FC, nr 33) pojawiają się także jako konsekwencje uwarunkowań historycznych lub kulturalnych, w jakich znajduje się określony podmiot moralny. Można także mówić o trudnościach związanych ze spełnieniem danej normy, która stoi na straży określonej i zdeterminowanej wartości. Warto odwołać się w takich przypadkach do prawa stopniowalności rozumianego jednak jako proces pedagogiczny i wychowawczy tej samej normy, którą zamierza się przekazać.

Poza tym Amoris laetitia wskazuje na pewne ograniczenia w określeniu właściwego procesu rozeznania, przywołując przy tym pewne okoliczności łagodzące w wydaniu negatywnego osądu. Powołując się na nauczanie Katechizmu Kościoła katolickiego, Franciszek przypomina, że „odpowiedzialność za działanie mogą zostać zmniejszone, a nawet zniesione, na skutek niewiedzy, nieuwagi, przymusu, strachu, przyzwyczajeń, nieopanowanych uczuć oraz innych czynników psychicznych lub społecznych" (AL, nr 302, KKK, nr 1735). Kontynuując odwołanie do wykładni doktryny wiary i zasad moralności, papież przywołuje także uwarunkowania, które redukują moralną odpowiedzialność, mając na uwadze miejsce, w którym Katechizm Kościoła katolickiego mówi o „niedojrzałości uczuciowej, nabytych nawykach, stanach lękowych lub innych czynnikach psychicznych czy społecznych" (AL, nr 302; KKK, nr 2352). Przy takiej linii interpretacji przypomina także nauczanie Jana Pawła II, który poddając krytyce kategorię opcji fundamentalnej, zaznaczał, że „niewątpliwie mogą zaistnieć sytuacje bardzo złożone i niejasne pod względem psychologicznym, które wywierają wpływ na podmiotową poczytalność grzesznika" (RP, nr 17). Odniesienie do wypowiedzi tego typu powoduje, że Franciszek, powołując się na „bardzo odpowiednie” (AL, nr 302) finalne wnioski ojców synodalnych, uważa, że „w pewnych okolicznościach ludzie napotykają na poważne trudności, by działać inaczej. [...] Rozeznanie duszpasterskie, uwzględniając prawidłowo uformowane sumienie osób, musi czuć się odpowiedzialne za te sytuacje" (AL, nr 302; Franciszek 2015b, nr 85). Prawidłowa formacja sumienia nie wykracza zatem poza ramy przyjętego przez Amoris laetitia duszpasterskiego rozeznania, ale stanowi jego integralny element, tym bardziej że - jak zaznacza papież 
sumienie może [...] uznać nie tylko to, że dana sytuacja nie odpowiada obiektywnie ogólnym postanowieniom Ewangelii. Może także szczerze i uczciwie uznać to, co w danej chwili jest odpowiedzią wielkoduszną, jaką można dać Bogu i odkryć z jakąś pewnością moralną, że jest to dar, jakiego wymaga sam Bóg pośród konkretnej złożoności ograniczeń, chociaż nie jest to jeszcze w pełni obiektywny ideał (AL, nr 303).

\section{Newmanowska wizja formacji sumienia}

Papież Franciszek dotyka w swoim dokumencie istotnego zagadnienia, jakim jest właściwy sposób kształtowania sumień chrześcijan. Jeśli chcemy dobrze zgłębić tajemnice sumienia, warto odwołać się do tego, którego życie określane jest jako ,jeden wielki komentarz do problematyki sumienia" (Ratzinger 1999, s. 37). Mowa o Johnie Henrym Newmanie, którego często nazywa się także doktorem sumienia - Doctor conscientiae (por. Geissler 2012, s. 1). Wśród bogatego dorobku naukowego brytyjskiego myśliciela owo stwierdzenie znajduje uzasadnione urzeczywistnienie. W nakreślonej przez Newmana wizji koncepcja sumienia konstytuuje wyraz troski o właściwe ukształtowanie jego fenomenu. Jest to szczególnie ważne względem ludzi, których Amoris laetitia przedstawia jako osoby poszukujące drogi wyjścia z trudnej i skomplikowanej sytuacji, a które często, zawierając małżeństwo oraz zakładając rodzinę, nie dbają o własne sumienie i „bezmyślnie kroczą przez świat" (Surmiak 2011, s. 513).

John Henry Newman, wskazując na odpowiednie podejście do tematyki formacji sumienia, pisał, że „o naszym sumieniu też można powiedzieć, że bije godziny i że nie będzie wybijać ich dobrze, jeżeli nie zostanie należycie uregulowane dla wypełniania właściwej sobie funkcji. Polega ono na głośnym obwieszczaniu zasady słuszności w szczegółach postępowania tak samo, jak poczucie pewności jest jasnym świadectwem prawdy" (Newman 1989, s. 187). W prezentowanej przez Newmana koncepcji sumienie nie jest kategorią nieomylną i zdarza mu się popełniać błędy. W celu uniknięcia ewentualnych uchybień oraz zwiększenia precyzji ogłaszanych sądów moralnych nie należy zapominać o procesie formacji, który należy do powinności podmiotu moralnego. To konieczny element, bo „tam, gdzie człowiek przestaje odwoływać się do sumienia, albo ujmuje jego osądy wyłącznie w duchu subiektywizmu i relatywizmu, nie ma szans na prawdziwą formację moralną" (Nagórny 2006, s. 9).

Nie możemy zapominać, że sumienie jest częścią uniwersalnej własności ludzkości, choć oczywiście pojmowanie dobra i zła może być różne u poszczególnych ludzi w zależności od właściwej formacji. Brytyjski myśliciel 
ostrzegał, że już w jego „czasach dla znacznej części społeczeństwa prawo i wolność sumienia zasadza się właśnie na obywaniu się bez sumienia, ignorowaniu Prawodawcy i Sędziego, niezależności od niewidzialnych zobowiązań (Newman 2002, s. 45). Spoglądając na współczesne społeczeństwa, nie sposób zaprzeczyć aktualności postawionej diagnozy, tym bardziej że w dobie obecnej trudno jest także znaleźć opozycję do słów pisanych przez Newmana, a zamykających się w stwierdzeniu, że gdy myśli się o sumieniu, to raczej mówi się o prawie do „myślenia, mówienia, pisania i działania, zgodnie z własnym osądem i nastrojem, bez jakiejkolwiek myśli o Bogu" (tamże, s. 45). Ludzie „żądają tego, co uważają za prerogatywę [...], aby każdy był swoim własnym panem we wszystkim i wyrażał, co mu się podoba" (tamże, s. 44). Takie odniesienie do fenomenu sumienia, prezentowane także przez współczesne pary, które popadły w trudności z tytułu wytrwania w związku małżeńskim, nie zawiera w sobie odpowiedzialności wobec Stwórcy, ale raczej postrzegane jest jako zupełnie niezależne i całkowicie autonomiczne (Geissler 2012, s. 8). Parafrazując starą łacińską maksymę nemo iudex in causa sua, należy zaznaczyć, że także w odniesieniu do właściwego rozeznania na płaszczyźnie małżeńskiej osoby borykające się z problemami zobowiązane są do poddania swoich sumień stosownej formacji dokonywanej wewnątrz wspólnoty Kościoła.

Istotnym obowiązkiem każdej osoby jest zatem troska o właściwą formację sumienia, albowiem odkąd człowiek ma prawidłowo uformowane sumienie, nabywa również zdolność do podejmowania czynów w koherencji z obiektywną rzeczywistością moralną. Funkcją sumienia jest bycie osobistym przewodnikiem w zakresie wiary i moralności, ,a w swej roli przewodnika jest [ono] wyposażone we wszystko, co jest mu potrzebne do spełniania swojej funkcji” (Newman 1989, s. 296-297). Zdaniem brytyjskiego myśliciela, rola sumienia wiąże się z ukierunkowaniem osoby ku dobru i prawdzie, tak aby mogła ona odkryć i realizować obiektywną prawdę moralną. „W swojej elementarnej i najważniejszej funkcji dla moralnego życia działa sumienie jako czujnik, albo organ, który człowiekowi wskazuje, co powinien czynić" (Schockenhoff 2006, s. 185). Według Newmana sumienie okazuje się przewodnikiem po zawiłych i często krętych drogach realizacji wymagań moralnych. Poza tym daje człowiekowi prawidłowe rozeznanie wartości oraz stwarza możliwość dokonania moralnie najlepszego z możliwych wyboru.

Zadaniem każdego podmiotu moralnego, szczególnie osób trapiących się trudnościami w dziedzinie życia małżeńskiego, jest dbałość o odpowiednią formację sumienia, która czyni osądy moralne ,pewne nie tylko w sensie subiektywnym [...], lecz by również obiektywnie wskazywały na dobro i prawdę" (Gałecki 2012, s. 257). Osoby, ku którym skierowana jest papieska adhortacja Amoris laetitia, powinny także pamiętać o tym, że na sumienie nie należy patrzeć z perspektywy kreatora prawdy i zasad moralnych, ale jedynie 
lektora powinności oraz prawdy moralnej; instrumentu i narzędzia w odniesieniu do odkrywania Bożych prawd. W duszpasterskim działaniu ważne jest to, aby „zachęcać do dojrzałości sumienia światłego, uformowanego, któremu towarzyszy odpowiedzialne i poważne rozeznanie pasterza, i proponować coraz większe zaufanie do łaski” (AL, nr 303). Rozeznanie duszpasterskie, o jakie apeluje Franciszek, jest procesem dynamicznym oraz ,zawsze powinno być otwarte na nowe etapy rozwoju i nowe decyzje pozwalające na zrealizowanie ideału w pełniejszy sposób” (tamże).

Dbałość o właściwe ukształtowanie sumienia w kontekście Amoris laetitia jest podstawowym warunkiem uczciwego rozeznania oraz aplikacji wymagających norm moralnych. Papieski dokument może wydawać się nowatorski, choć nie należy zapominać o zawartym w nim także odwołaniu do wcześniejszego dorobku teologicznego, wypracowanego już przez św. Tomasza z Akwinu i kontynuowanego przez wielkiego papieża, jakim był Jan Paweł II. Nie sposób pominać wkładu papieża Polaka, twórcy encykliki Dives in misericordia, w rozwój rozumienia tajemnicy miłosierdzia. Franciszek nie zrywa z wcześniejszym nauczaniem, ale jeszcze dobitniej je akcentuje, otaczając Bożym miłosierdziem trudne sytuacje, w których znajdują się małżonkowie poszukujący prawdy moralnej dotyczącej realizacji ich zobowiązań. Podstawowym kryterium rozeznania, jakim kieruje się papież Franciszek, jest odnalezienie zaginionej owcy (por. Łk 15,1-7). W tym kontekście papież przypomina o różnych sytuacjach „słabości i niedoskonałości” (AL, nr 269), które nie mogą przesłonić walki o dobro moralne i duchowe człowieka. Wśród dwóch ścieżek, jakie możemy dostrzec w historii Kościoła, nie może nam się przytrafić pomylenie tej właściwej.

Dwie logiki spotykamy w całych dziejach Kościoła: usuwanie na margines i włączanie [...]. Drogą Kościoła, począwszy od Soboru Jerozolimskiego, jest zawsze droga Jezusa: droga miłosierdzia i integracji [...]. Drogą Kościoła jest niepotępianie nikogo na wieczność; ofiarowanie miłosierdzia Boga wszystkim ludziom, którzy szczerym sercem o to proszą [...]. Prawdziwa miłość zawsze jest bowiem niezasłużona, bezwarunkowa i bezinteresowna! (AL, nr 269; Franciszek 2015a, s. 257).

Zarysowana przez Franciszka w Amoris laetitia perspektywa jest głęboko przesiąknięta tajemnicą miłosierdzia, jaką papież pragnie włączyć w działanie duszpasterskie całej wspólnoty Kościoła powszechnego, szczególnie w odniesieniu do aplikacji określonych norm moralnych. To, że we współczesnym świecie małżonkowie niewłaściwie rozumieją porządek moralny i często znaj- 
dują się w swoistego rodzaju labiryncie decyzji moralnych, w żaden sposób nie skreśla ich z pola zasięgu uzdrawiającego spojrzenia miłości Boga bogatego w miłosierdzie.

\author{
THE ISSUE OF UNDERSTANDING THE MORAL ORDER
}

IN THE PERSPECTIVE OF MERCY RECOGNIZED BY A WELL-FORMED CONSCIENCE IN THE APOSTOLIC EXHORTATION AMORIS LAETITIA

\title{
SUMMARY
}

The Church has never lost sight of its concern for well-being of marriage and the family in its teaching. This is a subject that has always occupied an important place in Church's documents and has been the subject of a deep reflection. Pope Francis, in his recent apostolic exhortation Amoris laetitia, also took a stance in this matter. His voice in the debate concerning the family is especially important today when the family is affected by the dynamics of deep cultural and social changes.

Recognizing difficult situations which modern families often face, Pope Francis offers a look filled with merciful love, which has healing, soothing and elevating power. It is also worth noting that the document itself was signed during the Jubilee Year of Mercy. The presented perspective is deeply rooted in the mystery of mercy, also with reference to the understanding by married couples the question of the moral order and the application of certain moral norms.

The following article is an attempt of interpreting Pope Francis' recent exhortation from the viewpoint of multi-faceted difficulties, with modern families and marriages in terms of norms and principles of morality. The key to understanding the papal document is the mystery of divine mercy. The healing touch of merciful love is an essential remedy that heals and cures the wounds of present-day marriages and families.

Słowa kluczowe: Amoris laetitia; małżeństwo i rodzina; miłosierdzie; porządek moralny; formacja sumienia

Keywords: Amoris laetitia; marriage and family; mercy; moral order; formation of conscience

\section{BIBLIOGRAFIA}

\section{Źródło podstawowe}

Franciszek (2016), Adhortacja apostolska o miłości w rodzinie Amoris laetitia, „Acta Apostolicae Sedis" 108, s. 311-446. 


\section{Nauczanie soborowe}

Sobór Watykański II (2002), Konstytucja duszpasterska o Kościele w świecie współczesnym Gaudium et spes, w: Sobór Watykański II, Konstytucje, dekrety, deklaracje, red. M. Przybył, Poznań, s. 526-606.

Sobór Watykański II (2002), Dekret o pasterskich zadaniach biskupów w Kościele Christus dominus, w: Sobór Watykański II, Konstytucje, dekrety, deklaracje, red. M. Przybył, Poznań, s. 232-254 .

\section{Nauczanie papieskie}

Jan Paweł II (1996), Adhortacja apostolska o zadaniach rodziny w świecie współczesnym Familiaris consortio, w: Adhortacje apostolskie Jana Pawła II, Kraków, s. 87-208.

Jan Paweł II (1999), Adhortacja apostolska o pojednaniu i pokucie w dzisiejszym posłannictwie Kościoła Reconciliatio et paenitentia, w: Jan Paweł II, Adhortacja apostolska Reconciliatio et paenitentia, Wrocław.

Jan Paweł II (1996), Encyklika o niektórych podstawowych problemach nauczania moralnego Kościoła Veritatis splendor, w: Encykliki Ojca Świętego Jana Pawła II, t. 2, Kraków, s. 531-637.

Franciszek (2015a), Homilia podczas Mszy św. z nowymi kardynatami, „Acta Apostolicae Sedis” 107 , s. 255-260.

Franciszek (2015), Bulla ustanawiająca nadzwyczajny Jubileusz Miłosierdzia Misericordiae vultus, „Acta Apostolicae Sedis” 107, 399-420.

Franciszek (2015b), Relacja końcowa po XIV zwyczajnym zgromadzeniu Synodu Biskupów „,Misja i powołanie rodziny w Kościele $i$ w świecie wspótczesnym”, „Acta Apostolicae Sedis” 107, s. 1161-1221.

\section{Literatura przedmiotu i pomocnicza}

Gałecki S. (2012), Spór o sumienie, Kraków.

Geissler H. (2012), Conscience and truth in the writings of blessed John Henry Newman, Rome.

Maiorano S. (1987), Coscienza e verità morale nel Vaticano II, w: La coscienza morale oggi, red. M. Nalepa, T. Kennedy, Roma, s. 259-278.

Nagórny J. (2006), Wprowadzenie, w: Formacja moralna. Formacja sumienia, red. J. Nagórny, T. Zadykowicz, Lublin, s. 9-12.

Newman J.H. (2002), List do Księcia Norfolk o sumieniu, tłum. A. Muranty, Bydgoszcz.

Newman J.H. (1989), Logika wiary, tłum. P. Boharczyk, Warszawa.

Olszanowski P. (2015), Wierność sumieniu w świetle wybranych dziet Johna Henry'ego Newmana oraz Konstytucji ,, Gaudium et spes”, „Teologia i Moralność” 17, s. 205-218.

Ratzinger J. (1999), Prawda, wartości, władza, thum. G. Sowiński, Kraków.

Schockenhoff E. (2006), Jaka pewność daje nam sumienie? Orientacja etyczna, thum. A. Marcol, Opole.

Surmiak W. (2011), Bt. Johna Henry'ego kard. Newmana (1801-1890) teologia sumienia, „Śląskie Studia Historyczno-Teologiczne" 44,2, s. 511-528.

Tomasz z Akwinu (1986), Suma teologiczna, t. XIII: Prawo, thum. P. Bełch, Londyn.

Yáñez M. (2016a), ,, Amoris laetitia”, non solo pastorale, „Avvenire” 158, s. 15.

Yáñez M. (2016b), Le ,, situazioni irregolari”, „Vita pastorale” 7, s. 44-47.

Piotr Olszanowski - ks. dr, kapłan diecezji bydgoskiej, absolwent Wydziału Teologii Moralnej Papieskiego Uniwersytetu Gregoriańskiego w Rzymie. W la- 
tach 2016-2018 jeden z wykładowców Wyższego Seminarium Duchownego w Bydgoszczy, gdzie prowadził wykłady z zakresu teologii moralnej. Zainteresowania naukowe obejmują współczesne zagadnienia teologii moralnej fundamentalnej oraz szczegółowej, filozofii moralności oraz etyki. 